\title{
Effect of temperature on seed germination of Bombax costatum Pellegr. \& Vuill. (Malvales: Malvaceae) from Ondo and Oyo States, Nigeria
}

\author{
M. O. Ojo
}

Forestry Research Institute of Nigeria. P.M.B. 5054 Ibaban. Oyo State. Nigeria. Email: ojobamideleakure@yahoo.com.

\begin{abstract}
Effect of temperature on seed germination of Bombax costatum Pellegr \& Vuill. (Malvales: Malvaceae), from four provenances in South Western Nigeria was investigated. A set of three replicates of 25 seeds per provenance were used for the experiment which was laid in a completely randomized block design. The seeds were exposed to fire temperature regimes for germination tests: $28{ }^{\circ} \mathrm{C}, 20{ }^{\circ} \mathrm{C}, 5{ }^{\circ} \mathrm{C}, 35{ }^{\circ} \mathrm{C}$ and $20{ }^{\circ} \mathrm{C}$. Seed germination was recorded for 4 weeks. Data obtained were subjected to analysis of variance. Result showed that significant differences in seed germination under varying temperature regimes $(\mathrm{P}<0.05)$. Interaction effect between temperature and provenances was not significant $(\mathrm{P}<0.05)$. seeds placed in ambient temperature had the highest mean number of germination (20.75) while the least mean value (0.17) was observed for cold room $\left(-20^{\circ} \mathrm{C}\right)$. B. costatum seeds should be exposed to ambient temperature so as to promote seed germination.
\end{abstract}

Keywords: Red-flowered silk cotton tree; Seed germination provenances; Temperature.

\section{Introduction}

In Nigeria, a high proportion of forests have changed an extent reduced by man's activities such as farming, overgrazing, use of fire for forest clearing as well as over exploitation without replacement. The increasing wide spread shortage of raw materials for pulp and paper has led to a search for new source of fibre (Udo Hitinah and Oluwadare, 2011), and Egbewole and Rotowa (2017) reported that pulp and paper has been
Received

May 29, 2019

Accepted

August 26, 2019

Released

August 31, 2019

Full Text Article

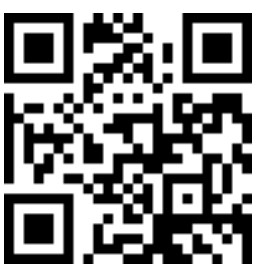

ORCID

(ㄱ) 0000-0003-0750-4431 M. 0. Ojo the largest traditional forest product imported into Nigeria.

Osadare (1995) and National Agricultural Research Project (NARP, 1995), investigated the suitability of some deciduous tree species as substitute sources of raw materials and identified Bombax costatum Pellegr \& Vuill. (Malvales: Malvaceae) as a candidate species for pulp and paper production. It is the red flowered deciduous kapok tree of the forest regions found in the lowland rainforest 
zone, woody savannas, woodlands, secondary forest and in outliers (Keay, 1989; Arbonnier, 2004). The tree grows up to $40 \mathrm{~m}$ high and $4 \mathrm{~cm}$ girth. In Ghana it is the most preferred species for food crop association and it is also considered for religious activities (Owusu-Sekyere, 1999). The trunk is armed with large conical woody spines.

Environmental factors which affect seed germination have been observed in seeds of many species (Finch-Savage and Leubner-Metzger, 2006). The principal factors influencing seed germination are temperature, water, oxygen and light of which temperature is the most significant (Hartmann et al., 2002) as it affects germination percentage and rate for non dormancy seeds. High germination percentage and rates with relatively good uniformity are important factors for successful seedling production. Germination conditions as tolerance range at which seeds will germinate vary with species and are related to the environment in which the plats normally grow. The temperature at which the seeds are maintained is that which is expected to give the quickest and meet complete germination of the sample. Temperature sensitive seeds may typically change their degree of dormancy according o environment.

Because of the lack of information on optimum temperature for seed germination of the species, this study was carried out to fill this gap so as to provide the most suitable temperature needed for the germination.

\section{Materials and method}

Seeds of Bombax costatum were obtained from four provenances in South Western Nigeria, Aponmu (latitude $7^{\circ} 20^{\prime}$ $\mathrm{N}$ and longitude $5^{\circ} 30^{\prime} \mathrm{E}$ ), Oluwa (latitude $6^{\circ} 55^{\prime} \mathrm{N}$ and $7^{\circ} 20^{\prime} \mathrm{N}$, and longitude $3^{\circ} 45^{\prime} \mathrm{E}$ and $4^{\circ} 32^{\prime} \mathrm{E}$ ) in Ondo State, Ibadan (latitude $7^{\circ} 26^{\prime} \mathrm{N}$ and longitude $3^{\circ} 54^{\prime} \mathrm{E}$ ), and Oyo (latitude $3^{\circ}$ $55^{\prime} \mathrm{N}$ and $4^{\circ} 42^{\prime} \mathrm{N}$ ) in Oyo State.
Seed germination test as carried out according to Abrah,(2011). The work surfaces were cleaned and disinfect with $70 \%$ alcohol solution. A $1 \%$ sodium hypochlorite solution was prepared and used for soaking the seeds for $3 \mathrm{~min}$ after which they were thoroughly rinsed for 4 times in distilled water. A set of three replicates of 25 seeds provenance were on Whatman's No. 9 filter paper and placed on transparent glass sheets. The substractum was moistened with $10 \mathrm{~m} / \mathrm{s}$ distilled water and kept sufficiently moist at all times to supply the necessary moisture to the seeds. The glass sheets were already inside copenhangen tanks at the seed store laboratory of Forestry Research Institute of Nigeria (FRIN). The tanks were adjusted to two temperature regimes, $28^{\circ} \mathrm{C}$ and $35^{\circ} \mathrm{C}$. Two thermometers were placed inside the tanks to monitor the temperature regimes.

Once germination started, germination counts were taken everyday for a month after which ungerminated seeds were discarded. The other experiment was carried out at National Center for Genetic Research and Biotechnology (NAGRAB). Moor plantation Ibadan. Three replicates were prepared for germination in petri-dishes lined with 2 sterile moist filter paper (Whatman's No. 9) and placed on shelves inside the different storage media after sterilization. The temperature has already being regulated to $20^{\circ} \mathrm{C}$.

Germination counts were also taken for a month and ungerminated seeds were discarded. Data collected were subjected to analysis of variance where significant, LSD test was used to separate the means.

\section{Results}

The analysis of variance for effect of temperature on seed germination is presented in Table 1, significant differences were recorded in seed germination under varying temperature regimes for the four provenances 
$(\mathrm{P}<0.05)$, However, interaction effect between temperature and provenance was not significant (Table 1), highest germination percentage of $89.3 \%$ attained for Aponmu under ambient temperature $\left(28^{\circ} \mathrm{C}\right)$ this was followed by Oyo with $88.0 \%$ while seeds from Oluwa had $81.3 \%$. The least germination percentage was recorded for Ibadan $(73.3 \%)$, for seeds placed in $35^{\circ} \mathrm{C}$ temperature regime, highest germination percentage of $72.0 \%$ was obtained in seeds from Aponmu followed by Oluwa with $68.0 \%$, Ibadan $(61.3 \%)$ and the lowest germination of $60 \%$ was observed for Oyo seeds. For seeds placed in $20 \%$ temperature regime Aponmu seeds had $81.3 \%$, Oyo seeds had $76.0 \%$ closely followed by Oluwa forest, Oyo and
Ibadan recorded 26.7\%. Least germination percentage for the entire provenance was observed under $20^{\circ} \mathrm{C}$, Aponmu and Oyo had $1.3 \%$ while no germination was observed for seeds from Oluwa and Ibadan provenances (Table 2).

The highest mean number of germination $(2,020.75)$ was observed for ambient temperature $\left(28{ }^{\circ} \mathrm{C}\right)$ while the least mean number of germination (0.17) was observed for seeds under $-20^{\circ} \mathrm{C}$. The highest mean number of germination (13.87) was observed for Aponmu while the least mean number of germination (0.17) was observed for Aponmu while the least mean value of 11.13 was observed for seeds from Ibadan (Table 3).

Table 1. Analysis of variance for effect of temperature on seed germination.

\begin{tabular}{|l|c|c|c|c|}
\hline Parameter & df & MS & F & P-level \\
\hline Temperature & 4 & 881.21 & 338.93 & 0.00 \\
\hline Provenance & 3 & 18.86 & 7.25 & 0.00 \\
\hline Temperature $\mathrm{x}$ & & & & \\
\hline provenance & 12 & 3.26 & 1.26 & 0.28 \\
\hline Error & 40 & 2.60 & & \\
\hline
\end{tabular}

Note: significant at 5\% probability level.

Table 2. Effect of temperature on percentage seed germination across the four provenances.

\begin{tabular}{|l|c|c|c|c|c|}
\hline & \multicolumn{5}{|c|}{ Temperature regime } \\
\hline Provenance & $28{ }^{\circ} \mathrm{C}$ & $5{ }^{\circ} \mathrm{C}$ & $20^{\circ} \mathrm{C}$ & $35^{\circ} \mathrm{C}$ & $-20^{\circ} \mathrm{C}$ \\
\hline Aponmu & 89.3 & 33.3 & 81.3 & 72 & 1.3 \\
\hline Oyo & 88.0 & 26.7 & 76.0 & 68 & 1.3 \\
\hline Oluwa & 81.3 & 32.0 & 73.3 & 61.3 & - \\
\hline Ibadan & 73.3 & 26.7 & 61.3 & 60.0 & - \\
\hline
\end{tabular}


Table 3. Mean values for effect of temperature on seed germination of Bombax costatum from the provenances.

\begin{tabular}{|l|c|}
\hline Temperature & Mean Number of Germination \\
\hline $28^{\circ} \mathrm{C}$ & $20.75_{\mathrm{a}}$ \\
\hline $35^{\circ} \mathrm{C}$ & $16.33_{\mathrm{c}}$ \\
\hline $20^{\circ} \mathrm{C}$ & $18.25_{\mathrm{b}}$ \\
\hline $5{ }^{\circ} \mathrm{C}$ & $7.42_{\mathrm{d}}$ \\
\hline$-20^{\circ} \mathrm{C}$ & $0.17_{\mathrm{de}}$ \\
\hline LSD provenance & 1.29 \\
\hline Oluwa & $12.73_{\mathrm{a}}$ \\
\hline Oyo & $12.60_{\mathrm{ab}}$ \\
\hline Ibadan & $11.13_{\mathrm{b}}$ \\
\hline Aponmu & $13.87_{\mathrm{a}}$ \\
\hline LSD & 0.68 \\
\hline
\end{tabular}

\section{Discussion}

Temperature is one of the most important environmental factor which influence germination and different seeds germinate at varying temperature. Temperature markedly influence the rate of many germination processes such as, absorption of water, translocation of soluble hormones, respiration, cell division and elongation. Effect of temperature on seed germination was significant in this study, seeds placed in ambient temperature $\left(28^{\circ} \mathrm{c}\right)$ had the highest number of germination, while the seeds placed in $-20^{\circ} \mathrm{C}$ had the least number of germination. This agrees with Somade and Obiaga (1993) who found that temperature of $25{ }^{\circ} \mathrm{C}-30{ }^{\circ} \mathrm{C}$ is suitable for Terminalia superba. This is also in consonance with the findings of Muhl et al. (2011) who reported that optimum temperature for seed germination of Moringa oleifera under green condition ranged from $20^{\circ} \mathrm{C}-30^{\circ} \mathrm{C}$. Longman and Jenik (1987) had earlier discovered that many tropical tree species are sensitive to small temperature differences seed at $28{ }^{\circ} \mathrm{C}$ temperature regime exhibited a significantly $\quad(\mathrm{P}<0.05) \quad$ highest germination. Dwyer and Erickson (2018) reported that there were evidences that warmer germination temperatures accelerated germination in some Australian annual plant species.

The germination of the seeds was impeded by the low temperature. This is in consonance with Lars (2000) and Muhl et al. (2011) who reported that some species are generally susceptible to chilling injury at low temperatures. Lars (2000) also discovered that most tropical lowland species like Bombax costatum require temperature of $20^{\circ} \mathrm{C}$ or more for germination to proceed.

However, Pinus and Eucalyptus species need to be exposed to chilling conditions as the species need low temperature for germination to proceed (Sirikul, 1994).

The variations observed among the provenances could be due to physiological or genetic factors such as embryo sterility or other growth inhibitions also there should be differential nutrient status as well as differences in vigour in the seed lots from the provenances.

\section{Conclusion}

This study has shown that effect of temperature on seed germination was significant. There were variations in temperature tolerance for the provenances. Seeds placed in ambient temperature $\left(28{ }^{\circ} \mathrm{C}\right)$ had the highest number of germination, while the seeds 
placed $20{ }^{\circ} \mathrm{C}$ had the least number of germination, Bombax costatum seeds were generally susceptible to chilling injury at $5{ }^{\circ} \mathrm{C}$ and $20{ }^{\circ} \mathrm{C}$ thus leading to poor germination.

It is recommended that seeds of Bombax costatum should be exposed to promote seed germination.

Also more research should be carried out on other important environmental factors that can influence the rate and germination of the species of its purpose uses.

\section{Conflict of interests}

The author declares that there are no conflicts of interest.

\section{References}

Aborah, J. B. Testing seed viability using sample germination tests. ECHO Asia Notes, 11, 2011. Available from: <https://www.echocommunity.org/ resources/0ea0f610-2062-4c5d-8dc70e0449fdec1c>. Accessed on: Apr. 22, 2019.

Arbonnier, M. Trees, shrubs and lianas of West African dry zones. CTRAD, 2004.

Divyer, J. M.; Erickson, T. E. Warmer seed environments increase germination fractions in Australian winter annual plant species. Ecosphere, v. 7, no. 10, e01497, 2018. https://doi.org/10.1002/ecs2.1497

Egbewole, Z. T.; Rotowa, 0. J. Effects of declining paper industry in Nigeria economy and the way forward. American Journal of Agriculture and Forestry, v. 5, no. 6, p. 181187, 2017.

Finch-Savage, W. E.; Leubner-Metzger, G. Seed dormancy and the control of germination. New Phytologist, v. 171, no. 3, p. 501-523, 2006. https://doi.org/ 10.1111/j.1469-8137.2006.01787.x

Hartmann, H. T.; Ketser, D. E.; Davies, F. T.; Geneve, R. L. Plant propagation: Principles and practices. 7. ed. New York: Prentice Hall, 2002.

Keay, R. W. J. Trees of Nigeria. Oxford: Clarendon Press, 1989.

Lars, S. Guide to handling of tropical subtropical forest seed kerselten. Danida: Danida Forest Seed Centre, 2000.

Longman, K. A.; Jenik, J. Tropical forest and its environment. Longman Scientific and Technical Paper, 347, 1998.

Muhl, Q. E.; Du Tolt, E. S.; Robertse, P. J. Temperature effect on seed germination and seedling growth of Moringa oleifera (Lam.) seed. Science \& Technology, v. 39, p. 208213, 2011.

NARP - National Agricultural Research Project. Medium term research plan nationally coordinated research programme for forestry. 1995.

Osadare, A. 0. Preliminary investigation into pulping properties of Sterculia oblonga. Nigerian Journal of Forestry, v. 26, no. 172, p. 32-34, 1995.

Owusu-Sukyere, E. Some indigenous trees for agrofoestry in the derived savanna zone of Ghana. Journal of Forestry, v. 8, p. 53-58, 1999.

Sirikul, W. Seed production of pines in Thailand. Proceedings of the International Symposium on Genetic Conservation and Production of Tropical Forest Seed, Thailand Canada Forest Tree Seed Centre Project, p. 229-232, 1994.

Somade, A. F.; Obiaga P. C. Effects of temperature and light conditions on the germination of Terminalia superba seeds. Nigerian Journal of Forestry, v. 23, no. 2, p. 95-97, 1993.

Udohitinah, J. S.; Oluwadare, A. D. Pulping properties of kraft pulp of Nigerian-grown kenaf (Hibiscus cannabinus L.). Bioresources, v. 6, no. 1, p. 751-761, 2011.

License information: This is an open-access article distributed under the terms of the Creative Commons Attribution License, which permits unrestricted use, distribution, and reproduction in any medium, provided the original work is properly cited. 